\title{
Ciąża, poród i połóg u kobiety po przebytym w dzieciństwie rozległym urazie miednicy oraz obustronnej wysokiej amputacji kończyn dolnych - opis przypadku
}

\author{
Pregnancy, delivery and puerperium in a woman after extensive pelvic bone fracture \\ and bilateral high lower limb amputation in childhood - a case report
}

\author{
Wioletta Mikołajek-Bedner', Zbigniew Celewicz², Anna Grzymała-Figura², Rafał Rzepka', Sebastian \\ Kwiatkowski', Małgorzata Sokołowska', Aleksandra Rajewska', Andrzej Torbé1凶
}

1 Pomorski Uniwersytet Medyczny w Szczecinie, Klinika Położnictwa i Ginekologii, al. Powstańców Wlkp. 72, 70-111 Szczecin

2 Pomorski Uniwersytet Medyczny w Szczecinie, Klinika Perinatologii, Położnictwa i Ginekologii, ul. Siedlecka 2, $72-010$ Police

$\triangle$ torbea@wp.pl

\begin{abstract}
Introduction: The aim of study was to analyze two pregnancies, deliveries and puerperal periods in a woman who had experienced bilateral lower limb amputation, pelvic bone fracture and severe injury of the urinary tract and reproductive organs. Case report: At the age of 4 she was the victim of a traffic accident, getting squashed by a trolley car, which caused crush wounds to both lower limbs and extensive perineal injury. Surgical intervention consisted of bilateral lower limb amputation at the level of the coxofemoral joint, and suturing of the torn vagina and rectum, with a temporary artificial anus formed from the sigmoid colon. Subsequent reconstructive surgery made spontaneous and well-controlled urination and defecation possible. The severe bodily injury experienced in the early life of the patient caused irreversible physical disability, accompanied, obviously, by psychological trauma. Despite this, at the age of 42 , the patient decided to procreate.

The first pregnancy was complicated by hyperthyroidism. Delivery by caesarean section was performed in the $31^{\text {st }}$ week
\end{abstract}

of gestation because of the premature rupture of membranes. Before delivery the patient was given a standard course of corticosteroids to accelerate foetal maturation. The second pregnancy was complicated not only by hyperthyroidism, but also by recurrent tachycardia and gestational diabetes mellitus. The patient received a standard dose of corticosteroids in the $32^{\text {nd }}$ week of gestation. Caesarean section was performed in the $36^{\text {th }}$ week of gestation because of spontaneous labour onset.

During both pregnancies no neurologic abnormalities were found in the patient. She was able to asses foetal movements and uterine activity adequately, which made ambulatory perinatal care possible. The reconstructive surgery of the urinary and digestive tract that the patient underwent in her childhood was not only a strong risk factor for operative delivery complications, but also because changes in anatomy and the potential presence of adhesions could have affected the pregnancy course itself. Keywords: delivery; lower limbs amputation; pregnancy; traffic accident.

\begin{abstract}
ABSTRAKT
Wstęp: Celem pracy było przedstawienie przebiegu ciąż, porodów i połogu u 42-letniej pacjentki, która w dzieciństwie przebyła obustronną wysoką amputację kończyn dolnych, złamanie kości miednicy oraz uszkodzenie układu moczowo-płciowego. Opis przypadku: Pacjentka w 4. r.ż. uległa wypadkowi tramwajowemu, doznając zmiażdżenia obu kończyn dolnych oraz rozległego urazu krocza. Dokonano wówczas obustronnej amputacji ud w stawach biodrowych. Rozerwaną pochwę i odbytnicę zaopatrzono chirurgiczne, wytworzono sztuczny odbyt na okrężnicy esowatej. Po licznych operacjach rekonstrukcyjnych pacjentka mogła samoistnie oddawać mocz i stolec, kontrolując potrzeby fizjologiczne.

Pierwsza ciąża powikłana była nadczynnością tarczycy. Ciążę ukończono drogą cięcia cesarskiego w 31. tyg. z powodu przedwczesnego pęknięcia błon płodowych po przeprowadzeniu
\end{abstract}

sterydoterapii. Kolejna ciąża pacjentki powikłana była także nadczynnością tarczycy, okresową tachykardią oraz cukrzycą ciężarnych. W 32. tyg. zastosowano sterydoterapię. Ciążę zakończono w 36. tyg. drogą cięcia cesarskiego z powodu rozpoczynającego się porodu.

U pacjentki nie stwierdzano zaburzeń neurologicznych, była w stanie prawidłowo ocenić aktywność ruchową płodu i ewentualną czynność skurczową macicy, co pozwoliło na ambulatoryjne prowadzenie obu ciąż. Przebyte operacje naprawcze w obrębie układu moczowego oraz dolnego odcinka przewodu pokarmowego stanowiły nie tylko istotny czynnik ryzyka powikłań porodu operacyjnego drogą cięcia cesarskiego, ale również, z uwagi na zmienioną anatomię i możliwą obecność rozległych zrostów, mogły wpłynąć na przebieg ciąży.

Słowa kluczowe: amputacja kończyn dolnych; ciąża; poród; wypadek komunikacyjny. 


\section{WSTĘP}

Coraz większa liczba kobiet o znacznym stopniu niepełnosprawności fizycznej decyduje się na posiadanie potomstwa. Większość kobiet niepełnosprawnych ruchowo jest płodna i może urodzić zdrowe dziecko, jednakże u kobiet z tej grupy bez wątpienia ciąża niesie ze sobą duże ryzyko, a jej przebieg jest zdecydowanie bardziej uciążliwy niż dla kobiet sprawnych fizycznie. U wielu z kobiet niepełnosprawnych podjęcie decyzji o urodzeniu dziecka wiąże się z lękiem dotyczącym nie tylko przebiegu samej ciąży, lecz również potencjalnych trudności w opiece nad dzieckiem i jego wychowaniem.

Pacjentki po przebytym rozległym urazie ze zmiażdżeniem obu kończyn dolnych, ze złamaniem kości miednicy z uszkodzeniem narządów płciowych, układu moczowego i przewodu pokarmowego wymagają leczenia przez wielodyscyplinarny zespół oraz długotrwałej rehabilitacji $[1,2]$. W okresie rozrodczym kobiety po tak rozległym urazie stają przed dylematami dotyczącymi możliwości zajścia w ciążę, kontynuowania jej bezpiecznego dla siebie i dziecka oraz optymalnego czasu i sposobu rozwiązania [3, 4]. Wyjątkowo rzadko położnik musi odpowiedzieć na takie pytania, co jest tym bardziej trudne, iż w piśmiennictwie znaleźć można głównie doniesienia na temat ciężarnych po przebytych urazach obręczy kostnej miednicy lub schorzeniach neurologicznych prowadzących do wyłączenia funkcji kończyn dolnych [3, 4 , $5,6,7,8,9,10]$.

Celem pracy było przedstawienie przebiegu ciąż, porodów i połogu u pacjentki po przebytej w dzieciństwie obustronnej wysokiej amputacji kończyn dolnych, złamaniu kości miednicy oraz uszkodzeniu układu moczowo-płciowego.

\section{OPIS PRZYPADKU}

Do Poradni Przyklinicznej Kliniki Położnictwa i Ginekologii Pomorskiego Uniwersytetu Medycznego w Szczecinie (PUM) zgłosiła się 42-letnia ciężarna w 11. tyg. pierwszej ciąży (na podstawie daty ostatniej miesiączki). Pacjenta w 4. r.ż. uległa wypadkowi tramwajowemu, doznając zmiażdżenia obu kończyn dolnych oraz rozległego urazu krocza. W okolicy krocza stwierdzono wówczas ziejącą ranę zachodzącą przez odbyt na okolicę kości krzyżowej z otwartym złamaniem obu kości łonowych.

Zaopatrując obrażenia, zespół chirurgów Oddziału Chirurgii Dziecięcej Miejskiego Szpitala Dziecięcego w Szczecinie amputował prawe udo w okolicy podkrętarzowej, zachowując staw biodrowy; kikut lewego uda wyłuszczono w stawie biodrowym; odwarstwioną skórą podbrzusza i prawego pośladka pokryto ranę po stronie prawej; po stronie lewej pełne pokrycie ran skórą okazało się niemożliwe; rozerwaną pochwę i odbytnicę zaopatrzono chirurgicznie; wytworzono ponadto nadłonową przetokę pęcherzową z powodu niemożności zlokalizowania ujścia zewnętrznego cewki moczowej.

W drugim etapie leczenia operacyjnego (w 3. dniu hospitalizacji) w celu zminimalizowania ryzyka powikłań wytworzono sztuczny odbyt na okrężnicy esowatej; z powodu zacieku moczowego w powłokach brzusznych otwarto pęcherz moczowy, zaopatrzono od wewnątrz uszkodzenia jego przedniej ściany, a następnie przez ujście pęcherzowe cewki moczowej wyprowadzono na krocze cewnik Nelatona, utrzymując przetokę nadłonową.

W trzecim etapie leczenia operacyjnego (3 tyg. po wypadku) z powodu martwicy wyłuszczono w stawie biodrowym pozostały kikut prawego uda, przeszczepiając skórę pobraną z kończyn górnych na ziarninujące, oczyszczone rany.

W kolejnym etapie ( 5 tyg. po wypadku) uzupełniono przeszczepy, pokrywając całkowicie rany, a także usunięto cewnik nadłonowy, co spowodowało samoistne zamknięcie się przetoki. Po 3 miesiącach usunięto cewnik z pęcherza moczowego i odtworzono ciągłość jelita grubego. Dziewczynka samoistnie oddawała mocz i stolec, kontrolując potrzeby fizjologiczne [1].

Podczas badania ginekologicznego w trakcie pierwszej wizyty w Poradni Patologii Ciąży stwierdzono, że okolicę sromu i krocza są zniekształcone przez liczne guzowate blizny i zaciągnięcia skóry. Z powodu całkowicie zmienionej anatomii badanie położnicze per vaginam było możliwe jedynie po wskazaniu przez ciężarną wejścia do pochwy. W trakcie badania stwierdzono: część pochwową twardą, skierowaną do tyłu, długości ok. 2 cm, z ujściem zewnętrznym zamkniętym; trzon macicy kulisty, rozpulchniony, wielkością odpowiadający ok. 11-tygodniowej ciąży; przydatki obustronnie niezmienione. Na podstawie badania ultrasonograficznego potwierdzono rozpoznanie pojedynczej ciąży wewnątrzmacicznej; oceniono czas jej trwania na 13 tyg. i 5 dni oraz potwierdzono prawidłową budowę zarodka. Ciężarna nie zgłaszała żadnych dolegliwości, nie przyjmowała na stałe innych leków poza preparatem bisoprololu stosowanym od mniej więcej roku z powodu okresowego kołatania serca. Zalecono ciężarnej przyjmowanie kwasu foliowego $(0,4 \mathrm{mg} / \mathrm{d})$, wykonanie standardowych kontrolnych badań laboratoryjnych, skierowano na konsultację kardiologiczną (bez istotnych odchyleń poza tachykardią ciężarnej) i wyznaczono termin kolejnej wizyty za ok. 4 tyg.

Do 18. tyg. ciąża przebiegała bez powikłań. W 18. tyg. ciężarna trafiła na szpitalny oddział ratunkowy z tachykardią i złym samopoczuciem. Otrzymała siarczan magnezu we wlewie kroplowym, po którym dolegliwości ustąpiły. Na kontrolnej wizycie położniczej nie stwierdzono odchyleń w badaniu położniczym. Poza tachykardią (ok. 112 na min) nie stwierdzono również odchyleń w badaniu przedmiotowym. Na podstawie dodatkowo zleconych oznaczeń poziomów TSH, fT3 i fT4 postawiono rozpoznanie nadczynności tarczycy i wdrożono leczenie preparatem propylotiouracylu. W ciągu kilku dni uzyskano poprawę samopoczucia ciężarnej i zwolnienie częstości rytmu serca do ok. 90 uderzeń na min.

Około 22. tyg. ciąży pacjentka zgłosiła się na wizytę z powodu obrzęku i zmian pęcherzowych na sromie, z których pobrano materiał na posiewy bakteriologiczne i wydano skierowanie na konsultację dermatologiczną. Konsultujący dermatolog postawił rozpoznanie kłykcin kończystych. Bez względu na wynik konsultacji, z uwagi na charakter zmian 
na sromie (pęcherze ze znacznym obrzękiem) i dolegliwości ciężarnej (świąd), wdrożono miejscowe leczenie preparatami przeciwgrzybicznymi i sterydowymi, uzyskując poprawę. Po ustąpieniu zmian pęcherzowych oraz obrzęku zapalnego zmiany na sromie przybrały charakter brodawek, jak w typowym obrazie kłykcin kończystych. Uzyskane wyniki posiewów ze zmian były ujemne. W trakcie kolejnych systematycznych wizyt kontrolnych nie stwierdzano nieprawidłowości w stanie przedmiotowym i podmiotowym ciężarnej oraz w badaniach laboratoryjnych. Jedynie w wykonanym skriningowym teście obciążenia glukozą wykazano nieprawidłową wartość glikemii po obciążeniu, ale w trakcie dalszej diagnostyki, na podstawie wyników testu diagnostycznego według Światowej Organizacji Zdrowia, wykluczono cukrzycę ciężarnych. W ramach przygotowania do ewentualnego wcześniejszego rozwiązania ok. 30. tyg. ciąży przeprowadzono konsultację anestezjologiczną i chirurgiczną. Ustalono, że po osiągnięciu względnej dojrzałości płodu ciężarną należy rozwiązać elektywnym cięciem cesarskim w znieczuleniu podpajęczynówkowym, w ewentualnej gotowości asysty chirurgicznej z uwagi na przebyte w dzieciństwie operacje w obrębie miednicy mniejszej. Podano betametazon celem stymulacji dojrzewania układu oddechowego płodu. Ciężarną rozwiązano drogą cięcia cesarskiego w 31. tyg. ciąży w warunkach dyżuru (26 grudnia 2008 r.) z powodu przedwczesnego odpłynięcia płynu owodniowego oraz porodu przedwczesnego w toku. Urodzono noworodka niedonoszonego płci żeńskiej o masie 1715 g, w stanie ogólnym dobrym (wg skali Apgar w 5. min życia 10 pkt). Powłoki brzuszne rodzącej otwarto cięciem prostym i stwierdzono zrost jelita grubego z przednią ścianą jamy brzusznej po stronie lewej od granicy cięcia. Nie stwierdzono innych nieprawidłowości wynikających z przebytego leczenia i dalsze etapy operacji przebiegały w sposób typowy. Przebieg okresu pooperacyjnego był niepowikłany. Położnicę wypisano w 7. dobie po cięciu cesarskim w stanie ogólnym dobrym, bez dziecka, którego leczenie kontynuowano w Klinice Neonatologii PUM. Dalszy przebieg połogu nie był powikłany. Położnica karmiła noworodka piersią.

Po 9 miesiącach od rozwiązania pacjentka ponownie trafiła do Poradni Patologii Ciąży Kliniki Położnictwa i Ginekologii PUM, skierowana przez lekarza ginekologa z Rejonowej Poradni K w 8. tyg. drugiej ciąży. Rozpoznanie i czas trwania ciąży potwierdzono badaniem USG. Ciężarną skierowano na pilną konsultację endokrynologiczną oraz konsultację kardiologiczną (bez istotnych odchyleń poza okresową tachykardią) i wdrożono leczenie propylotiouracylem oraz verapamilem, a w przypadku uczucia kołatania serca zalecono podawanie nifedypiny drogą podjęzykową. W trakcie drugiej ciąży ciężarna wymagała okresowych modyfikacji leczenia zaburzeń czynności tarczycy z uwagi na epizody niedoczynności; w diagnostycznym teście obciążenia glukozą uzyskano wyniki nieprawidłowe i rozpoznano cukrzycę ciężarnych - ciężarna nie zgłosiła się na konsultację diabetologiczną i nie stosowała się do zaleceń dotyczących diety. Skriningowe badania USG potwierdzały prawidłowy rozwój płodu z niskim ryzykiem aberracji chromosomowych.
Z uwagi na wywiad ogólny i położniczy w 32. tyg. ciąży podano betametazon celem stymulacji dojrzewania układu oddechowego płodu.

Ciążę zakończono cięciem cesarskim w 36. tyg. (26 lutego 2010 r.) z powodu rozpoczynającego się porodu w Klinice Medycyny Matczyno-Płodowej PUM, gdzie ciężarna trafiła z objawami zagrażającego porodu przedwczesnego pod postacią czynności skurczowej macicy. Zabieg przeprowadzono w znieczuleniu ogólnym. Urodzono niedonoszonego noworodka płci męskiej o masie 2360 g, w stanie ogólnym dobrym (wg skali Apgar w 5. min życia 9 pkt). Przebieg operacji, okresu pooperacyjnego oraz połogu był niepowikłany. Położnicę wypisano w 7 . dobie po operacji, bez dziecka, które kontynuowało leczenie w Klinice Neonatologii PUM. Położnica karmiła noworodka piersią. Pacjentka zgłosiła się na rutynową kontrolę poporodową 4 tyg. po cięciu cesarskim. Nie kontynuowała kontroli w Poradni Przyklinicznej.

\section{DYSKUSJA}

Ciężarne po przebytych urazach rdzenia kręgowego i wynikających z tego wyłączeniach funkcji kończyn dolnych lub ich amputacjach borykają się z problemami dotyczącymi nie tylko upośledzenia możliwości swobodnego samodzielnego poruszania się, lecz także z powikłaniami neurologicznymi, do których należą m.in. upośledzenie czucia. Są to trudności w ocenie aktywności ruchowej płodu lub czynności skurczowej macicy (w zależności od poziomu uszkodzenia rdzenia kręgowego), zaniki mięśni dna miednicy i mięśni obręczy miednicy, spastyczność, zwiększona aktywność i reaktywność układu autonomicznego, demineralizacja kości, a także zwiększone ryzyko infekcji w układzie moczowym, powikłań zakrzepowo-zatorowych oraz niedokrwistości [5, 7, 8, 9]. Zatem opisaną ciężarną trudno porównać z grupą pacjentek z powikłaniami neurologicznymi. Była ona w stanie prawidłowo ocenić aktywność ruchową płodu i ewentualną czynność skurczową macicy, co umożliwiało odpowiedni nadzór w warunkach ambulatoryjnych. Pacjentka nie wymagała z tego powodu częstszych kontroli monitorujących stan płodu oraz ryzyko porodu przedwczesnego. Podobnie przebyte przez nią urazy nie prowadziły do upośledzenia funkcji mięśni szkieletowych ze wszystkimi możliwymi tego konsekwencjami, wynikającymi m.in. z osłabienia siły mięśni dna miednicy. Wydaje się, że amputacja kończyn dolnych nie miała istotnego wpływu na przebieg ciąż. Największy problem stanowić mogły przebyte złamania miednicy, urazy układu moczowego i przewodu pokarmowego oraz anatomiczne skutki przebytych operacji naprawczych, których nie można było ocenić u pacjentki w pierwszym trymestrze ciąży. Zniekształcenia miednicy kostnej trudno jednoznacznie ocenić jedynie na podstawie badania zewnętrznego. Istotniejszy problem stanowią zniekształcenia wnętrza kanału rodnego, które mogą utrudniać prawidłowe rozrastanie się macicy ciężarnej oraz prowadzić do nieprawidłowych położeń i ułożeń płodu. Zniekształcenia miednicy kostnej mogą mieć 
również istotny wpływ na przebieg porodu fizjologicznego, znacznie go utrudniając lub uniemożliwiając, będąc istotnym czynnikiem ryzyka m.in. dysproporcji płodowo-miednicowej [11]. Przebyte operacje naprawcze w obrębie układu moczowego oraz dolnego odcinka przewodu pokarmowego stanowią nie tylko istotny czynnik ryzyka powikłań porodu operacyjnego drogą cięcia cesarskiego, lecz również, z uwagi na zmienioną anatomię i możliwą obecność rozległych zrostów, mogą wpłynąć na przebieg ciąży. W podobnych przypadkach można rozważyć jeszcze na etapie planowania ciąży podjęcie próby oceny anatomii badaniami obrazowymi, choć znaczenie prognostyczne wyników takich badań budzi bardzo wiele kontrowersji [5, 10, 11].

Opisany przypadek dotyczy bardzo ciężkiego uszkodzenia ciała, do którego doszło we wczesnym dzieciństwie, skutkującego nieodwracalnym kalectwem i ciężkim urazem psychicznym. Mimo to pacjentka w 42. r.ż. zdecydowała się na posiadanie potomstwa. Nawet kobiety ze znacznym stopniem niepełnosprawności odczuwają potrzebę macierzyństwa, a współczesna medycyna powinna dążyć do zapewnienia im realizacji takiej możliwości. Ze względu na wzrastającą liczbę kobiet w wieku reprodukcyjnym dotkniętych ciężką niepełnosprawnością, głównie w wyniku wypadków komunikacyjnych, problemy związane $\mathrm{z}$ ciążą $\mathrm{w}$ tej grupie kobiet spotykane będą coraz częściej.

\section{PIŚMIENNICTWO}

1. Błaszczyk J, Szymański S. Dwa przypadki urazowych amputacji kończyn dolnych u dzieci. Warszawa: PZWL; 1976. p. 87-91.

2. Kregor PJ, Routt ML Jr. Unstable pelvic ring disruptions in unstable patients. Injury 1999;30:19-28.

3. Riehl JT. Caesarean section rates following pelvic fracture: a systematic review. Injury 2014;45:1516-21. doi: 10.1016/j.injury.2014.03.018.

4. Cannada LK, Barr J. Pelvic fractures in women of childbearing age. Clin Orthop Relat Res 2010;468(7):1781-89. doi: 10.1007/s11999-010-1289-5.

5. Ehrenberg HM, Mercer BM, Catalano P, Fisgus JR. Pregnancy in a spinal cord-injured bilateral total leg amputee: management and considerations. Am J Obstet Gynecol 2003;188(4):1096-9.

6. Ben-Aderet N. Pregnancy following hind-quarter amputation. J Obstet Gynaecol Br Commonw 1965;72:306-7.

7. Bertschy S, Bostan C, Meyer T, Pannek J. Medical complications during pregnancy and childbirth in women with SCI in Switzerland. Spinal Cord 2016;54(3):183-7. doi: 10.1038/sc.2015.205.

8. Ghidini A, Simonson M. Pregnancy after spinal cord injury: a review of the literature. Top Spinal Cord Inj Rehabil 2011;16(3):93-103. doi.org/10.1310/ sci1603-93.

9. Baker ER, Cardenas DD. Pregnancy in spinal cord injured women. Arch Phys Med Rehabil 1996;77(5):501-7.

10. Goswami D, Kochhar PK, Suri T, Zutshi V, Batra S. Obstetric and gynecological outcome in a patient with traumatic pelvic fracture and perineal injures. J Obstet Gynaecol Res 2012;38(8):1118-23. doi: 10.1111/j.14470756.2011.01838.x.

11. Tsvieli O, Sergienko R, Sheiner E. Risk factors and perinatal outcome of pregnancies complicated with cephalopelvic disproportion: a population-based study. Arch Gynecol Obstet 2012;285(4):931-6. doi: 10.1007/ s00404-011-2086-4. 